Environmental Research Journal 6(3): 151-157, 2012

ISSN: 1994-5396

(C) Medwell Journals, 2012

\title{
Study of Auto Purification Capacity of River Atuwara in Nigeria
}

\author{
${ }^{1}$ D.O. Omole, ${ }^{2}$ I.K. Adewumi, ${ }^{3}$ E.O. Longe and ${ }^{1}$ A.S. Ogbiye \\ ${ }^{1}$ Department of Civil Engineering, Covenant University, P.M.B. 1023, \\ Canaanaland, Ota, Ogun State, Nigeria \\ ${ }^{2}$ Department of Civil Engineering, Obafemi Awolowo University, Ile-Ife, Osun State, Nigeria \\ ${ }^{3}$ Department of Civil and Environmental Engineering, University of Lagos, \\ Akoka-Yaba, Lagos State, Nigeria
}

\begin{abstract}
The aim of this study was to study and predict the self purification capacity of River Atuwara. This was done primarily by measuring the Dissolved Oxygen (DO) downstream of a pre-selected pollution discharge point on River Atuwara and then predicting the same using the modified Streeter-Phelps equations. Other data gathered from each of the 17 sampling stations on River Atuwara and used in the analysis included Biochemical Oxygen Demand (BOD), pH, stream velocity, stream depth and distance. Predicted DO deficit trend lines were first fitted by retaining the original re-aeration coefficient component, $\mathrm{k}^{2}$ of the modified Streeter-Phelps equation (USGS equation) and subsequently by substituting it with Atuwara Reaeration Coefficient Model. It was found that the latter displayed better predictive capacity.
\end{abstract}

Key words: Surface water quality, pollution, BOD, stream reaeration coefficient, River Atuwara, Ota

\section{INTRODUCTION}

Flowing surface water bodies have the natural capacities to purify themselves from the pollutions that come into them from external sources (Garg, 1998; Longe and Omole, 2008). The process of purification is achieved mainly through the absorption and dissolution of atmospheric oxygen from the water body surface. This absorbed and Dissolved Oxygen (DO) is required for the chemical process of breaking down biological and chemical pollutants thereby reducing their concentration and ultimately eliminating the pollution threat over a period of time (Alam et al., 2007). However, there are other natural factors that affect the auto purification capacity of water bodies. These include the water body velocity, depth, discharge and temperature (Agunwamba et al., 2006). Fast flowing water bodies are able to absorb atmospheric oxygen faster than slow moving water bodies. Similarly, turbulent water bodies are generally very clean because of the natural capacity to absorb and digest pollutants at a very high rate. Stagnant water bodies on the other hand tend to become septic when there is high pollutant content because of the low rate of oxygen absorption. Furthermore, the depth of the water body also affects the rate of diffusion and mixing of the absorbed oxygen (Kiely, 1998). Deeper water bodies require more time and bulk movement for the oxygen that was absorbed at the surface to mix evenly and reach the bottom of the channel. Similarly, discharge which is defined as the product of velocity and cross-sectional area of the water body affects the auto purification of water bodies. Furthermore, the importance of temperature on the auto purification process of a water body is reflected through the dissolved oxygen concentration level of any water body. Therefore, water bodies situated in temperate regions have higher DO concentration than water bodies situated in tropical regions (Henry and Heinke, 2005). At certain temperatures, the water cannot absorb oxygen beyond a certain level. The maximum DO level that a river can attain at a certain temperature is known as the saturated $\mathrm{DO}$. This ranges from $14.6 \mathrm{mg} \mathrm{L}^{-1}$ of $\mathrm{DO}$ at $0^{\circ} \mathrm{C}$ to $\mathrm{mg} \mathrm{L}^{-1}$ at $35^{\circ} \mathrm{C}$ (Weiner and Matthews, 2003).

The current study takes a look at the pollution and auto purification processes of River Atuwara which is one of the most important rivers in Ota, Ogun State, Nigeria. Due to multiple human activities on River Atuwara, both point and non-point pollutions have been affecting the water quality. The objective of this study therefore is to analyze the self-purification dynamics of a particular segment of interest on the river.

Study area: River Atuwara takes its source from the Adenrele area of Ifo district and traverses Ota Local Government Area in Ogun State (Fig. 1). The segment of importance on River Atuwara that was selected for the

Corresponding Author: D.O. Omole, Department of Civil Engineering, Covenant University, P.M.B. 1023, Canaanaland, Ota, Ogun State, Nigeria 


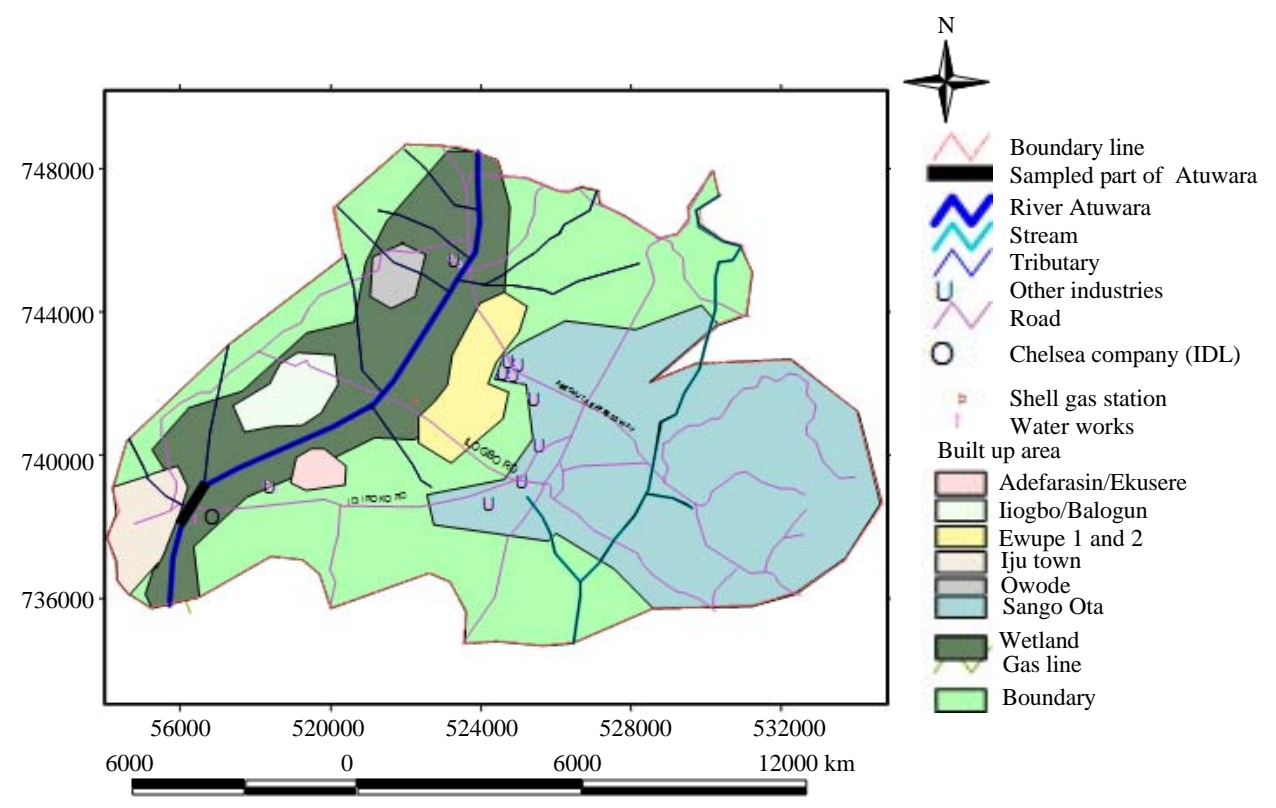

Fig. 1: Map of Ado/Odo Ota showing locations of interest

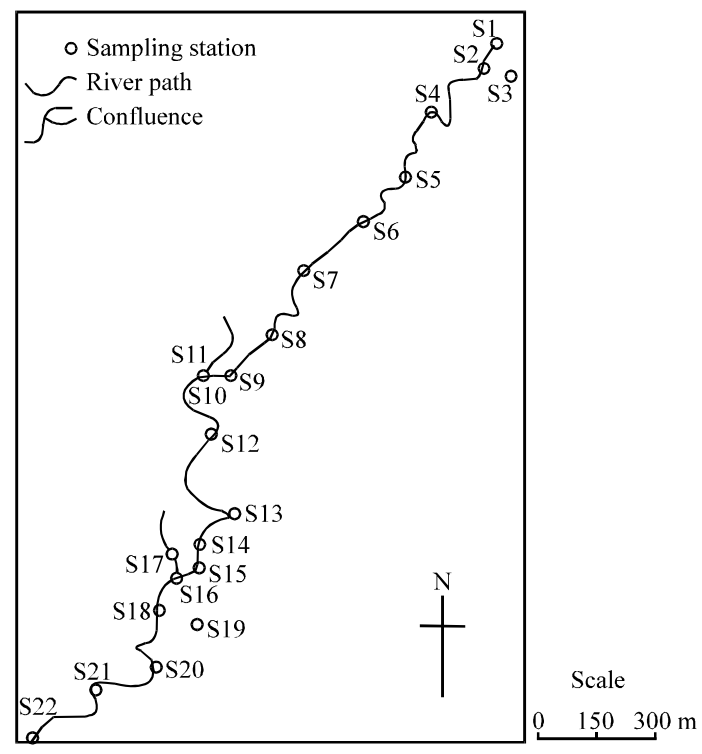

Fig. 2: The sampling stations on River Atuwara

study is a $1.3 \mathrm{~km}$ stretch (Fig. 2). This segment was identified and selected because of the numerous and conflicting water use activities taking place there. These activities include industrial effluent disposal, sand quarrying for construction purposes, religious activities such as baptism and animal sacrifices. Furthermore, wood loggers work around the river and use it to transport their produce. Other rivers such as River Balogun and another unidentified river form confluences with River Atuwara. These rivers impact on River Atuwara by importing unknown wastes from unidentified sources into River Atuwara or by serving as dilutants of the high concentration of wastes in River Atuwara. The State Water Corporation withdraws water for potable water supply to Ota residents from River Atuwara. Furthermore, residents of Iju town (Fig. 2) use the river water as a source of domestic water supply in its untreated state. They also, visit the river for recreation purposes such as swimming and animal hunting.

\section{MATERIALS AND METHODS}

The field study was carried out in January 2010 which was a dry season. The dry season is important because pollution has the highest impact on a receiving stream due to its dry weather flow (Henry and Heinke, 2005; Mehrdadi et al., 2006). The $1.3 \mathrm{~km}$ segment that was studied was traversed using a canoe. Total 22 sampling stations were chosen based on the peculiarity of the location rather than equidistance. Some of the peculiar locations include $\mathrm{S} 1$ which was marked $50 \mathrm{~m}$ upstream of the effluent discharge in order to note the water quality of the river just before pollution took place. $S 2$ is the point of effluent discharge into the river. S3 is a pool of raw effluent that is yet to mix with the river. Other locations of interest are $\mathrm{S} 9$ which is a point $10 \mathrm{~m}$ before the confluence of River Atuwara and River Balogun. S10 is the confluence itself and S11 is a location on River Balogun. Another location that was marked was a point where dredging activities take place (S13). A second confluence of River Atuwara and an unidentified river occurred 
further downstream. This was numbered S15-S17 in the same order as the first confluence. The points where the State's Water Corporation installed an intake, S19 and the place where villagers use the water for domestic purposes, S22 were also marked.

The river segment was divided into three reaches. Reach 1 consists of sampling stations, S2-S10. Reach 2 consists of sampling stations between S10 and S16. Reach 3 consists of sampling stations between S16 and S22. For the purpose of this study only 17 sampling stations were considered. Sampling stations S3, S1 1, S1 7 and S19 were not considered because they do not fall within the river's path. At each sampling station, water velocity was measured using Geopacks Stream Flow sensor, depth was taken at three points along each river cross section using Speedtech Portable Depth Sounder, the ambient and water temperature data were obtained using a Eurolab Digital Thermometer. The cross-section of the river was measured by stretching a tape across its width. Water $\mathrm{pH}$ was obtained using a handheld $\mathrm{pH}$ meter. The total distance of the segment and the global position of each sampling station was obtained with the aid of a Garmin Etrex Handheld GPS unit. All water samples were analyzed for DO and BOD using titrimetric method (Azide Modification). BOD water samples were stored in a series cooled Gallenkamp incubator at a controlled temperature of $20^{\circ} \mathrm{C}$. All obtained laboratory and bathymetric data were entered into an excel spreadsheet. Basic data handling, statistical analysis and other calculations were done with the aid of excel spreadsheet.

Theory: The study of the auto purification process of water bodies was introduced by Streeter and Phelps (1925), Streeter et al. (1936), Fair et al. (1971) and Lin and Lee (2007). Findings from their report demonstrated that when pollution enters a water body which initially has a saturated DO level, $\mathrm{D}_{\mathrm{s}}$ the dissolved oxygen content of the river dips immediately with an initial deficit, $D_{0}$. The DO continues to dip and after a certain distance downstream, it begins to recover thus giving a spoon shaped curve (Fig. 3). Curve A represents a scenario where the polluted river recovers without passing through the anaerobic $(\mathrm{DO}=0$ ). Curve $\mathrm{B}$ presents a case where the pollution leads to the river becoming septic (Anaerobic).

This stream pollution and recovery dynamics was represented by Streeter and Phelps (1925) in mathematical terms by the relationship given by Eq. 1 .

$$
\frac{d D(t)}{d t}=k_{1} L(t)-k_{2} D(t)
$$

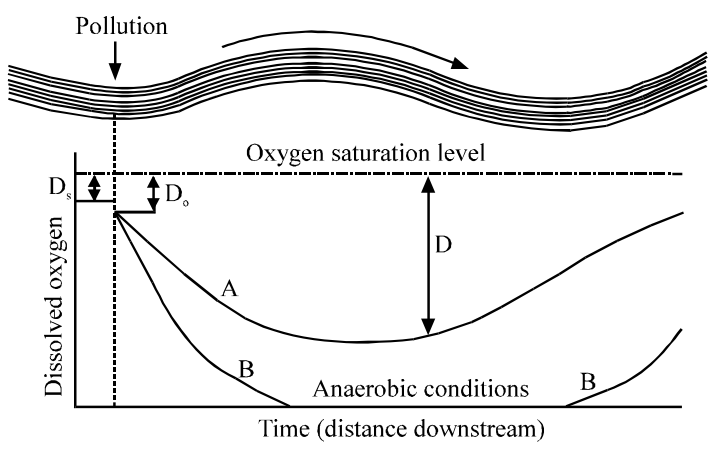

Fig. 3: The oxygen sag curve (Weiner and Matthews, 2003)

Where:

$\mathrm{k}_{1}=$ De-oxygenation constant

$\mathrm{k}_{2}=$ Re-aeration constant

$\mathrm{D}=$ Oxygen deficit

$\mathrm{L}=$ Ultimate first stage $\mathrm{BOD}$ of mix at the point of discharge $\mathrm{mg} \mathrm{L}^{-1}$

The pollution strength was given as a measure of Biochemical Oxygen Demand (BOD). The BOD is the quantity of oxygen required by any particular waste load to get broken down. Thus, a high BOD value indicates a waste load with a high concentration. When Eq. 1 is integrated, the result is (Waite and Freeman; 1977; Kiely, 1998; Longe and Omole, 2008):

$$
\mathrm{D}=\frac{\mathrm{L}_{\mathrm{a}}}{\mathrm{f}-1} 10^{-\mathrm{k}_{2} \mathrm{t}}\left\{1-10^{\left[-(\mathrm{f}-1) \mathrm{k}_{2} \mathrm{t}\right]}\left[1-(\mathrm{f}-1) \frac{\mathrm{D}_{\mathrm{a}}}{\mathrm{L}_{\mathrm{a}}}\right]\right\}
$$

Where:

$\mathrm{D}=$ The DO deficit $\left(\mathrm{mg} \mathrm{L}^{-1}\right)$ after time $\mathrm{t}$ (Fig. 3)

$\mathrm{L}_{\mathrm{a}}=$ Ultimate first stage BOD of mix at the point of discharge $\left(\mathrm{mg} \mathrm{L}^{-1}\right)$

$\mathrm{D}_{0}=$ Initial dissolved oxygen deficit of the mix at the mixing point $\left(\mathrm{mg} \mathrm{L}^{-1}\right)$

$k_{1}=$ De-oxygenation coefficient for the effluent which can be considered as equal to the $\mathrm{BOD}$ rate constant determined in the laboratory

$\mathrm{k}_{2}=\mathrm{Re}$-aeration coefficient for the stream

$\mathrm{t}=$ Time

$\mathrm{f}=\mathrm{k}_{2} / \mathrm{k}_{1}$ self-purification factor

Equation 2 is used in the prediction of the DO deficit in a river after pollution. However, the re-aeration coefficient component $\left(\mathrm{k}_{2}\right)$ of Eq. 2 which is a function of stream velocity, depth and temperature varies from location to location. The default $\mathrm{k}_{2}$ used in the original design is defined by Eq. 3 (Streeter et al., 1936). This equation is also known as the USGS equation: 
Environ. Res. J., 6 (3): 151-157, 2012

$$
\mathrm{k}_{2}=5.026 \frac{\mathrm{U}^{0.969}}{\mathrm{H}^{1.673}}
$$

For River Atuwara, the re-aeration coefficient was defined by Eq. 4 (Longe and Omole, 2008):

$$
\mathrm{k}_{2}=46.2679 \frac{\mathrm{U}^{1.5463}}{\mathrm{H}^{0.0128}}
$$

On this DO deficit curve, the critical point or the maximum oxygen deficit is located at $\mathrm{dD} / \mathrm{dt}=0$ (critical) and $\mathrm{d}^{2} \mathrm{D} / \mathrm{dt}^{2}<0$ (inflection).

Therefore, at critical point, Eq. 2 reduces to (Waite and Freeman, 1977; Kiely, 1998; Longe and Omole, 2008):

$$
\begin{gathered}
D_{c}=\frac{f_{a}\left\{f\left[1-(f-1) \frac{D_{a}}{L_{a}}\right]\right\}^{\frac{1}{(f-1)}}}{t_{c}=\frac{2.3}{k_{2}(f-1)} \log \left\{f\left[1-(f-1) \frac{D_{a}}{L_{a}}\right]\right\}} \\
D_{i}=\frac{(f+1) L_{a}}{f^{2}\left\{f^{2}\left[1-(f-1) \frac{D_{a}}{L_{a}}\right]\right\}^{\frac{1}{(f-1)}}}
\end{gathered}
$$

$$
\mathrm{t}_{\mathrm{i}}=\frac{2.3}{\mathrm{k}_{2}(\mathrm{f}-1)} \log \left\{\mathrm{f}^{2}\left[1-(\mathrm{f}-1) \frac{\mathrm{D}_{\mathrm{a}}}{\mathrm{L}_{\mathrm{a}}}\right]\right\}
$$

Where:

$\mathrm{D}_{\mathrm{c}}=$ The critical point or maximum oxygen deficit

$\mathrm{t}_{\mathrm{c}}=$ The critical time when the minimum dissolved oxygen occurs

$D_{i}=$ The $D O$ value at point of inflection

$\mathrm{t}_{\mathrm{i}}=$ The time it occurs. This is the DO value when the river begins to recover from the critical $\mathrm{DO}$ situation

\section{RESULTS AND DISCUSSION}

The mean water temperature at the time of sampling was $23.6^{\circ} \mathrm{C}$ with a saturated DO of the river of $8.58 \mathrm{mg} \mathrm{L}^{-1}$. The water temperature was rather low at this period of the year due to the harmattan season which is characterized by cold winds. The geographic location and the hydraulic properties of each sampling station are shown in Table 1.

Similarly, the physical and chemical properties of water samples taken from the sampling stations are shown in Table 1. It could be observed from the table that S15 had the highest DO value of $8.2 \mathrm{mg} \mathrm{L}^{-1}$ which is very close to the saturated dissolved oxygen level of

\begin{tabular}{|c|c|c|c|c|c|c|c|c|c|}
\hline $\begin{array}{l}\text { Sampling } \\
\text { station }\end{array}$ & Elevation (m) & $\begin{array}{c}\text { Relative } \\
\text { distance (m) }\end{array}$ & $\begin{array}{l}\text { Reach } \\
\text { distance }\end{array}$ & $\begin{array}{c}\text { Mean velocity } \\
\left(\mathrm{m} \mathrm{sec}^{-1}\right)\end{array}$ & $\begin{array}{l}\text { Time of travel } \\
\text { per reach }\left(\text { day }^{-1}\right)\end{array}$ & Mean depth (m) & $\mathrm{BOD}\left(\mathrm{mg} \mathrm{L}^{-1}\right)$ & $\mathrm{DO}\left(\mathrm{mg} \mathrm{L}^{-1}\right)$ & $\mathrm{pH}$ \\
\hline $\mathrm{S} 1$ & 17 & 0 & - & 0.377 & - & 0.69 & 12.0 & 7.0 & 5.6 \\
\hline S2 & - & 50 & 590 & 0.260 & 0.029 & 0.58 & 8.0 & 7.2 & 5.7 \\
\hline S3- & 11 & - & - & - & - & - & 46.0 & 6.4 & 4.2 \\
\hline S4 & 11 & 120 & - & 0.250 & - & 0.67 & 8.0 & 6.4 & 5.7 \\
\hline S5 & 13 & 220 & - & 0.193 & - & 0.81 & 6.0 & 6.0 & 5.7 \\
\hline s6 & 14 & 320 & - & 0.227 & - & 0.54 & 10.0 & 7.4 & 5.7 \\
\hline S7 & 14 & 420 & - & 0.220 & - & 1.03 & 24.0 & 8.0 & 5.7 \\
\hline S8 & 12 & 520 & - & 0.190 & - & 1.19 & 6.0 & 6.4 & 5.7 \\
\hline s9 & 14 & 630 & - & 0.162 & - & 0.81 & 10.0 & 8.0 & 5.1 \\
\hline $\mathrm{S} 10$ & - & 640 & 180 & 0.377 & 0.009 & 1.02 & 14.0 & 7.2 & 5.7 \\
\hline S11 & - & - & - & 0.151 & - & 0.45 & 26.0 & 8.2 & 5.9 \\
\hline $\mathrm{S} 12$ & 10 & 700 & - & 0.260 & - & 0.66 & 6.0 & 6.8 & 5.7 \\
\hline S13 & 9 & 750 & - & 0.122 & - & 1.80 & 18.0 & 7.4 & 7.2 \\
\hline S14 & - & 800 & - & 0.270 & - & 0.93 & 10.0 & 6.8 & 6.0 \\
\hline S15 & - & 820 & 480 & 0.417 & 0.031 & 0.41 & 16.0 & 8.2 & 5.8 \\
\hline S16 & 14 & 830 & - & 0.417 & - & 1.83 & 14.0 & 7.6 & 5.6 \\
\hline S17 & - & - & - & 0.139 & - & 1.46 & 34.0 & 5.8 & 5.1 \\
\hline S18 & - & 900 & - & 0.237 & - & 2.90 & 12.0 & 7.2 & 5.6 \\
\hline S19 & - & - & - & - & - & - & 18.0 & 7.6 & 5.6 \\
\hline $\mathrm{S} 20$ & 9 & 1000 & - & 0.162 & - & 1.12 & 8.0 & 7.4 & 5.6 \\
\hline $\mathrm{S} 21$ & 6 & 1150 & - & 0.057 & - & 1.38 & 10.0 & 6.8 & 5.6 \\
\hline $\mathrm{S} 22$ & 6 & 1300 & - & 0.013 & - & 0.65 & 24.0 & 7.8 & 5.6 \\
\hline
\end{tabular}
$8.58 \mathrm{mg} \mathrm{L}^{-1}$ of the river. This could be attributed to the fact that the station also has the highest value of flow velocity and coupled with a relatively shallow depth, the mixing of the absorbed atmospheric oxygen is enhanced. This corroborates the earlier assertion that high stream 
velocity aids re-aeration. Conversely, S16 which is only $10 \mathrm{~m}$ downstream of S1 5 and which has the same value of flow velocity as S15 but the DO value had dropped by several points. This is attributable to the fact that the water quality at S16 had been mixed with water coming from the relatively more polluted unidentified river, S17 which has a relatively low DO value of $5.8 \mathrm{mg} \mathrm{L}^{-1}$ and a relatively high $B O D$ value of $34.0 \mathrm{mg} \mathrm{L}^{-1}$.

Moreover, the $\mathrm{pH}$ of the river was generally low suggesting that the river is acidic. This is with the exception of S13 and S14 with $\mathrm{pH}$ values of 7.2 and 6.0 which fall within the normal range of neutrality. The $\mathrm{pH}$ of the water from S13 appeared normal probably because of the high human activities here which include laundry and sand dredging. Soap water is known to be highly alkaline and this has probably diluted the acidic river water. At $\mathrm{S} 14$, the $\mathrm{pH}$ had already begun to drop and at S15, the river water was back to its acidic state. Water coming from the unidentified river ( $\mathrm{S} 17$ ) was the most acidic with a $\mathrm{pH}$ value of 5.1. Low $\mathrm{pH}$ values suggest that certain acidic impurities were entering the river. This is detrimental to the environment because certain aquatic life would not be able to survive outside the normal $\mathrm{pH}$ range of water (NIS, 2007). Also, certain micro-organisms that help in breaking down biological wastes may not be able to survive in an acidic environment. One of the identified sources of acidity for River Atuwara was the industrial effluent from a distillery company which made contact with the river at S2. The raw effluent properties included a $\mathrm{pH}$ value of 4.2 (S3). Water from distilleries are highly hazardous and are known to contain pollutants like heavy metals that do not biodegrade easily (Fernandez et al., 2007).

Furthermore, the plot of DO along the path of the river (Fig. 4) displayed a marked difference from the expected normal spoon-shaped DO curve (Fig. 3). The DO curve along River Atuwara displayed sinusoidal tendencies which suggest that the progressive recovery process was being interrupted at intervals. Between S2

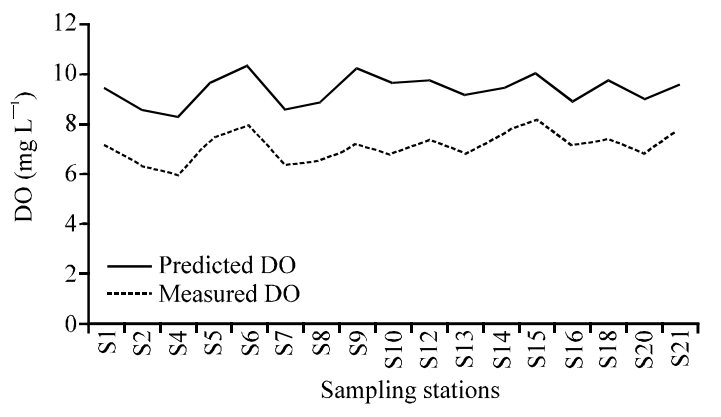

Fig. 4: DO deficit trend line against sampling stations using Atuwara Model in Eq. 2 and S5, the lowering of the DO was caused by the industrial effluent discharge into River Atuwara. The river began to recover at $\mathrm{S} 6$ but the process was interrupted at S8. The causes of lowering of the DO level at S8 include fishing activities. Fishing nets and hooks are common at this location. Some of these hooks have baits that include dead animals and fishes. Also, some of the fishes that are caught in the nets have died and are yet to be removed by the persons responsible for them. The river recovers again at $\mathrm{S} 9$ but the process is quickly interrupted by the natural inflow of River Balogun (S11) which had a lower velocity and higher $\mathrm{BOD}$ value. The other stations where the lowering of DO occurred along the river include S14, $\mathrm{S} 16$ and S21. These were caused by the laundry activities at S13, the relatively polluted water from the unidentified river (S17) and more fishing activities, respectively.

By substituting Eq. 4 into Eq. 2, the broken curve in Fig. 4 was obtained. However, when the Eq. 2 was used with a default $\mathrm{k}_{2}$ value (Eq. 3), the predicted DO deficit curve that was obtained is shown in Fig. 5. Furthermore from the prediction curve (Fig. 5) which was plotted by using Streeter et al. (1936) re-aeration coefficient in Eq. 2, the river is expected to become septic at S16 (Table 1). By using Atuwara Re-Aeration Coefficient Model in Eq. 2, the prediction curve (Fig. 4) suggests that the river is not expected to become septic at any point. This agrees with the measured data. This shows that the Atuwara Re-Aeration Coefficient Model gave better DO deficit prediction output than the Streeter et al. (1936) Re-Aeration Coefficient Model (Fig. 5).

The critical $\mathrm{DO}$ value, $\mathrm{D}_{c}$, calculated by using equation 5 was $1.82 \mathrm{mg}^{-1}$ and the time $t_{c}$, calculated from Eq. 6 was 0.008 days. These values were predicted to occur at S18. The predicted location for the occurrence of the critical DO (S18) is just $70 \mathrm{~m}$ downstream of the actual location (S17) with the maximum DO deficit (Table 1). The DO value at inflection, Di as calculated using Eq. 7 was $2.08 \mathrm{mg} \mathrm{L}^{-1}$ and the time, ti and place of recovery were 0.08 days and $\mathrm{S} 19$, respectively.

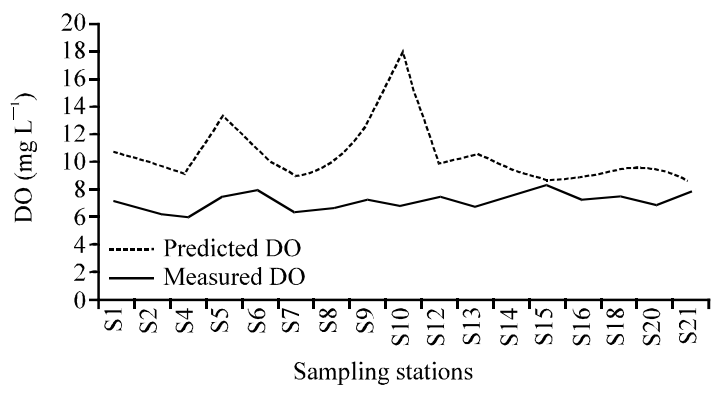

Fig. 5: DO deficit trend line against sampling stations using Streeter-Phelps Model in Eq. 2 
River Atuwara has a natural but limited capacity to purify itself from the numerous pollutants entering it mainly as an end result of human activities which include industrial effluent disposal, domestic wastes and economic activities. This capacity for auto-purification is enhanced through, an unobstructed flow velocity downstream of the river channel. However, the limitations of the potential for natural self-purification processes of this river are occasioned by relatively high ambient and water temperatures. The mean water temperature of $23.6^{\circ} \mathrm{C}$ at the time of this study which was one of the coldest periods in the year placed the DO saturation point at $8.58 \mathrm{mg} \mathrm{L}^{-1}$. At higher temperatures which at times go $>30^{\circ} \mathrm{C}$, the DO at saturation is expected to be $<8.58 \mathrm{mg} \mathrm{L}^{-1}$. This situation is further compounded when wastes that are high in BOD are released into the water body. These wastes quickly deplete the DO level of the river further. The industrial effluent being discharged into the river at its upstream section is highly acidic. This may be responsible for the low presence of biodiversity in the river. Also this acidic effluent could kill off all the micro-organisms that are responsible for breaking down the organic wastes in the river.

The plots of the measured DO suggest that the river auto-purification processes are being interrupted at frequent interval by point and non-point source pollutants. Some of the activities being carried out on Atuwara can be described as plain environmental abuse. The importance of River Atuwara to human life requires that protective measures that will further enhance the auto-purification capacity of River Atuwara needs to be taken. Some of these measures may include the activation of existing environmental laws in the enforcement of effluent quality standards. The exact nature of the waste from the other rivers that merge with River Atuwara should be investigated in order to determine the appropriate mitigation measures that should be taken.

\section{CONCLUSION}

Results also demonstrated that the auto-purification capacity of the river which is already limited by the relatively low DO saturation level is further threatened by the wastes being discharged into it at varying intervals. Some of the wastes which are non-biodegradable and acidic were also found to be interrupting the autopurification processes of the river. Water from River Atuwara requires treatment before it can be considered safe for consumption by its current users.

\section{ACKNOWLEDGEMENTS}

This research was supported by the International Foundation for Science, Stockholm, Sweden, through a grant to the D.O. Omole. The researchers are also grateful to the management of Covenant University, Obafemi Awolowo University and the University of Lagos, all in Nigeria, for providing the enabling environment for the conduct of this research.

\section{REFERENCES}

Agunwamba, J.C., C.N. Maduka and A.M. Ofosaren, 2006. Analysis of pollution status of amadi creek and its management. J. Water Supply Res. Technol., 55: 427-435.

Alam, J.B., M.R. Islam, Z. Muyen, M. Mamun and S. Islam, 2007. Water quality parameters along rivers. Int. J. Environ. Sci. Technol., 4: 159-167.

Fair, G.M., J.C. Meyer and D.A. Okun, 1971. Elements of Water Supply and Wastewater Disposal. 2nd Edn., John Wiley and Sons, NY.

Fernandez, B., I. Seijo, G. Ruiz-Filippi, E. Roca, L. Tarenzi and J.M. Lema, 2007. Characterization, Management and Treatment of Wastewater from White Wine Production. 2nd Edn., Water Science and Technology, NY, pp: 121-128.

Garg, S.K., 1998. Sewage Disposal and Air Pollution Engineering. 11th Edn., Khanna Publications, Environmental Engineering, pp: 2: 188-189.

Henry, J.G. and G.W. Heinke, 2005. Environmental Science and Engineering. Prentice-Hall of India, New Delhi, pp: 421-491.

Kiely, G., 1998. Environmental Engineering. McGraw-Hill Book Company, Singapore.

Lin, S.D. and C.C. Lee, 2007. Water and Wastewater Calculations Manual. McGraw Hill Companies Inc., USA.

Longe, E.O. and D.O. Omole, 2008. Analysis of pollution status of river illo, ota, Nigeria. Environmentalist, 28: 451-457.

Mehrdadi, N., M. Ghobadi, T. Nasrabadi and H. Hoveidi 2006. Evaluation of the quality and self-purification potential of tajan river using qual2e model. Iran. J. Environ. Health. Sci. Eng., 3: 199-204.

NIS, 2007. Nigerian standard for drinking water quality. ICS 13.060.20, Approved by Standard Organization of Nigeria (SON)Governing Council, Lagos and Abuja, Nigeria. http:/www.unicef.org/nigeria/ng_ publications_Nigerian_Standard_for_Drinking_ Water_Quality.pdf. 
Streeter, H.W. and E.B. Phelps, 1925. A Study of the Pollution and Natural Purification of the Ohio River. Public Health Bulletin, Public Health Service, Washington DC.

Streeter, H.W., C.T. Wright and R.W. Kehr, 1936. Measures of natural oxidation in polluted streams III. Sewage Works J., 8: 282-316.
Waite, T.D. and N.J. Freeman, 1977. Mathematics of Environment Processes. Lexington Books, London.

Weiner, R.F. and R. Matthews, 2003. Environmental Engineering, 4th Edn., Elsevier Sciences, New York. 